NBER WORKING PAPER SERIES

\title{
TAX EXPENDITURES, THE SIZE AND EFFICIENCY OF GOVERNMENT, AND IMPLICATIONS FOR BUDGET REFORM
}

\author{
Leonard E. Burman \\ Marvin Phaup \\ Working Paper 17268 \\ http://www.nber.org/papers/w17268
NATIONAL BUREAU OF ECONOMIC RESEARCH
1050 Massachusetts Avenue
Cambridge, MA 02138 \\ August 2011
}

Forthcoming in Jeffrey Brown, ed., Tax Policy and the Economy, Volume 26. We thank Charles Alamo, Thomas Barthold, Jeffrey Brown, John Buckley, Mihir Desai, Elizabeth Garrett, Laura Kalambokidis, Pam Moomau, John Palmer, Leslie Reinhorn, Robert Rozen, Dan Shaviro, Reed Shuldiner, John Spry, Eric Toder, Roberton Williams, Johnny Yinger, and seminar participants at the George Washington University, New York University, the University of Pennsylvania, and Pew Subsidyscope for helpful comments and discussions. The views expressed herein are those of the authors and do not necessarily reflect the views of any of the organizations with which we are affiliated, or the National Bureau of Economic Research.

NBER working papers are circulated for discussion and comment purposes. They have not been peerreviewed or been subject to the review by the NBER Board of Directors that accompanies official NBER publications.

(C) 2011 by Leonard E. Burman and Marvin Phaup. All rights reserved. Short sections of text, not to exceed two paragraphs, may be quoted without explicit permission provided that full credit, including (C) notice, is given to the source. 
Tax Expenditures, the Size and Efficiency of Government, and Implications for Budget Reform Leonard E. Burman and Marvin Phaup

NBER Working Paper No. 17268

August 2011, Revised October 2011

JEL No. H21,H24,H50,H62

\begin{abstract}
$\underline{\text { ABSTRACT }}$
One possible explanation for the difficulty in controlling the budget is that a major component of spending - tax expenditures - receives privileged status. It is treated as tax cuts rather than spending. This paper explores the implications of that classification and illustrates how it can lead to higher taxes, larger government, and an inefficient mix of spending (too many tax expenditures). The paper then analyzes alternative budgeting approaches that would explicitly incorporate and measure tax expenditures. It concludes by analyzing ways to control tax expenditures (and other spending) and the special challenges presented by tax expenditures.
\end{abstract}

Leonard E. Burman

Center for Policy Research

426 Eggers Hall

Syracuse, NY 13244

and NBER

leburman@maxwell.syr.edu

Marvin Phaup

Trachtenberg School of Public Policy and Public Ad

The George Washington University

601K Media and Public Affairs

Washington, D.C. 20052

MPhaup@gwu.edu 


\section{Introduction}

It has become almost a cliché that the projected growth of public debt in the United States is “unsustainable.” If current policies continue, the imbalance between spending and revenues will grow relative to the size of the economy, a path that may ultimately lead to a debt crisis. An explicit or implicit default by the largest economy in the world could have dire consequences for the economies of the US and the rest of the world. (Auerbach and Gale, 2011; Burman, Rohaly, Rosenberg, and Lim, 2010)

While many political leaders seem to understand this, controlling the debt has so far proven elusive. One reason is that two of the prime drivers of the debt-mandatory programs such as Social Security, Medicare, and Medicaid, and tax expenditures such as the tax subsidy for employer-sponsored health insurance-are very popular, not subject to the regular controls of the budget process, and growing fast.

Although mandatory spending and tax expenditures are similar in the sense that they are generally open-ended entitlements and operate outside the annual appropriations process, the costs of tax expenditures have the additional feature of being largely invisible to policy makers and citizens. Their cost is simply netted out of overall tax revenues. Tax expenditures are not treated as spending at all, but as reductions in taxes. Their hidden nature has made tax expenditures irresistible to policymakers of both parties-many political or policy goals can be achieved through stealthy spending programs that are framed as tax cuts.

The late economist, David Bradford, famously pointed out that virtually any spending program could be transformed into a tax expenditure. (Bradford 2003) To illustrate the point, he proposed a Weapons Supply Tax Credit, which would allow arms manufacturers to sell their ordinance to the pentagon in exchange for tax credits rather than cash. Instantly, the Defense Department's budget would decline by the amount of transformed spending. Tax revenues would decline by a similar amount (or more, if weapons suppliers demanded a premium on account of the complexities and uncertainties associated with the tax credit mechanism). But government would be doing exactly the same thing. Only the accounting would change. 
A real world example is the low-income housing credit. Enacted as part of the Tax Reform Act of 1986, it was modeled on HUD programs that subsidized the construction and rehabilitation of affordable housing. The credit replaced existing tax incentives that were extremely inefficient and poorly targeted and generally thought to help investors more than lowincome renters. Nonetheless, there are drawbacks to the credit program may be less efficient than an equivalent grant program. ${ }^{1}$ For example, the credits are only valuable to investors to the extent that they have tax liability, which creates uncertainty and thus causes investors to demand more in tax credits than they would a cash grant. Furthermore, since many low-income housing projects are organized by non-profits that cannot benefit from tax credits, the tax-exempt sponsors have to set up complex syndication schemes to reallocate credits to taxable investors, which adds to the cost of the projects. Industry advocates counter that the credit mechanism may offer some advantages, perhaps because it avoids inherent inefficiencies and uncertainties in the way traditional housing programs are run. Nonetheless, it's clear that the credit program is effectively a cash spending program, but one operated by the IRS rather than HUD.

The tax credit approach has commanded strong bipartisan support at least in part because of the useful obfuscation of its provenance and funding. ${ }^{2}$ But in 2009 the veil was lifted when the financial crisis caused many low-income housing credit investors to move into a tax loss position, making it difficult for states, which allocate the credits, to find investors willing to participate. The American Recovery and Reinvestment Act of 2009 allowed states to elect to issue cash grants in lieu of tax credits. (US Treasury 2009) This converted an estimated \$3 billion of tax expenditures into cash outlays in 2009. In 2010, the veil returned and the government's finances returned to their conventionally obscured state.

\footnotetext{
${ }^{1}$ Burman and McFarlane (2005) cite evidence from the 1990s of extremely high internal rates of return on tax credit financed investments. Ernst and Young (2010) estimated that these returns had declined from 18 percent in 1991 to rates of 6-7 percent in 2007. In private correspondence, Robert Rozen, a longtime advocate for the program, wrote that low-income housing projects had a foreclosure rate far lower than other real estate "and vastly superior to direct spending housing programs.”

${ }^{2}$ An additional advantage of the tax credit mechanism from the perspective of supporters of low-income housing programs is that it can represent a longer-term commitment since it does not need to be reauthorized by Congress. However, the credit was initially a temporary provision set to expire at the end of 1988. It was renewed several times before it was made permanent in 1993.
} 
Why would policymakers routinely favor tax expenditures over potentially more efficient spending alternatives? In a nutshell, it is because sponsors of explicit spending may be attacked for favoring high taxes and big government. A similar tax expenditure program makes both taxes and spending appear lower, which offers obvious political advantages.

In this paper, we develop a simple model that illustrates incentives created by current tax expenditure accounting. In the model, voters value both direct spending and tax expenditures, and dislike taxes and deficits. Their assessment of spending is based on their own experiencei.e., they value the roads they drive on or the credits or deductions they claim on their tax returns - but they assess the burden of current taxes and deficits based at least in part on government's aggregate measures. In this model, treating some spending as negative taxes results in (1) higher taxes and larger government and (2) an inefficient mix of spending (too many tax expenditures).

In contrast, transparent accounting for tax expenditures would result in less overall spending and a more efficient allocation of resources.

Beyond the simple theoretical model, there are significant challenges to accounting for tax expenditures. Tax expenditures are measured as deviations from a baseline "normal tax" system. The primary challenge is determining what that system should be. US government estimates use a fairly comprehensive income tax as the baseline. Some have suggested that a consumption tax should be used as the baseline in order to ensure that policies are not biased against savings tax incentives. Many of the largest tax expenditures, however, would be treated similarly under either baseline.

The paper then describes the current budget process and analyzes options for reform to the process that would explicitly and consistently incorporate and control tax expenditures. Beyond simply measuring tax expenditures and presenting them alongside explicit spending, the budget process could be modified to include a single cap on all spending - discretionary, mandatory, and tax expenditures - to facilitate tradeoffs of tax expenditures and explicit spending. For a cap to be effective, there must also be incentives for policy makers to abide by the cap. 


\section{Tax Expenditures: Meaning, Measurement, Consequences}

The term "tax expenditure” is attributed to Stanley S. Surrey who in 1967, as Assistant Secretary of the US Treasury for Tax Policy, instructed his staff to compile a list of preferences and concessions in the income tax that had the nature of expenditure programs. His goal was straightforward: to draw attention to these items in hopes of building momentum for tax reform, which would redirect the tax system toward its core function of raising revenues.

Surrey and coauthor, Paul R. McDaniel, defined the concept thus in their 1985 treatise on the subject:

The tax expenditure concept posits that an income tax is composed of two distinct elements. The first element consists of structural provisions necessary to implement a normal income tax, such as the definition of net income, the specification of accounting rules, the determination of the entities subject to tax, the determination of the rate schedule and exemption levels, and the application of the tax to international transactions. The second element consists of the special preferences found in every income tax. These provisions, often called tax incentives or tax subsidies, are departures from the normal tax structure and are designed to favor a particular industry, activity, or class or persons. They take many forms, such as permanent exclusions from income, deductions, deferrals of tax liabilities, credits against tax, or special rates. Whatever their form, these departures from the normative tax structure represent government spending for favored activities or groups, effected through the tax system rather than through direct grants, loans, or other forms of government assistance. (p. 3)

Seven years after Treasury first published a list of tax expenditures in 1967, the Congressional Budget Act of 1974 required the Administration to publish a tabulation of tax expenditures as part of its annual budget submission. The concept also gained widespread acceptance outside of the United States. Germany had invented the concept-if not the namemore than a decade before the US and included tax expenditure analysis in its budget process. (Shaviro 2004) Both Canada and the United Kingdom started publishing lists of tax expenditures in the late 1970s, and many other OECD countries had either adopted that practice or conducted preliminary studies by 1985. (Surrey and McDaniel, 1985)

In the U.S., the President's and congressional budget documents include tabulations of tax expenditures, defined as deviations from the "normal" individual and corporate income tax bases, along with estimates of the revenue losses from each. In principal, tax expenditures could also be defined with respect to other taxes, such as payroll taxes, estate taxes, and excise taxes, 
but that has not been done on a systematic basis. ${ }^{3}$ However, while explicit spending is integral to the budget presentation, tax expenditures are relegated to an appendix. They provide supplementary information to budget users, but they have no direct role in the budget process.

Furthermore, tax expenditures appear as reductions in taxes, but they are equivalent to cash spending. A more transparent accounting and reporting of tax expenditures would show both government spending and taxes to be higher than is currently reported. This is more than simply a matter of presentation. As explained below, this characterization of tax expenditures has motivated and facilitated a shift in spending away from traditional forms and into the tax code.

\subsection{Measuring Tax Expenditures}

Each year, the Treasury Department compiles a list of income tax expenditures, which is included in the Analytical Perspectives volume of the Administration's Budget released in early February. The Joint Committee on Taxation prepares a similar list for Congress. ${ }^{4}$ The purpose of the tax expenditure estimates is to raise the visibility of the cost of tax subsidies.

It is not clear that these compilations have had any effect on the use of tax expenditures because it is impossible to tell what the level would have been absent annual revelation. Surrey and McDaniel (1985) calculated that tax expenditures grew faster than GDP and much faster than cash outlays in the first fifteen years that tax expenditure estimates were produced, between 1967 and 1982. In 1986, there was a sharp reduction in the value of tax expenditures as a result of the Tax Reform Act of 1986, which reduced marginal tax rates (and reduced the value of deductions and exclusions) and eliminated many tax preferences. (See Figure 1.) The growth in the value of tax expenditures resumed through the 1990s because of increases in top tax rates and the introduction of some new tax subsidies such as the child tax credit (in 1997). Rate cuts in

\footnotetext{
${ }^{3}$ The US reported tax expenditures measured against a comprehensive estate and gift tax baseline until 2002. Davie (1994) discusses possible tax expenditures created by special excise tax provisions. Bankman, et al (this volume) discuss the exclusion for employer-sponsored health insurance-a large tax expenditure relative to both the income and payroll tax.

${ }^{4}$ This task was originally assigned to the Congressional Budget Office, but they ceded it to the Joint Committee on Taxation because the JCT was designated the official revenue estimator and was thus best prepared to estimate tax expenditures (Kleinbard 2010).
} 
2001 and 2003 trimmed tax expenditures again, but the total has since risen because of new tax expenditures (including a set of temporary economic stimulus tax measures enacted in 2009).

Figure 1. Number and Value (as Percent of GDP) of Tax Expenditure provisions,

\section{3-2009}

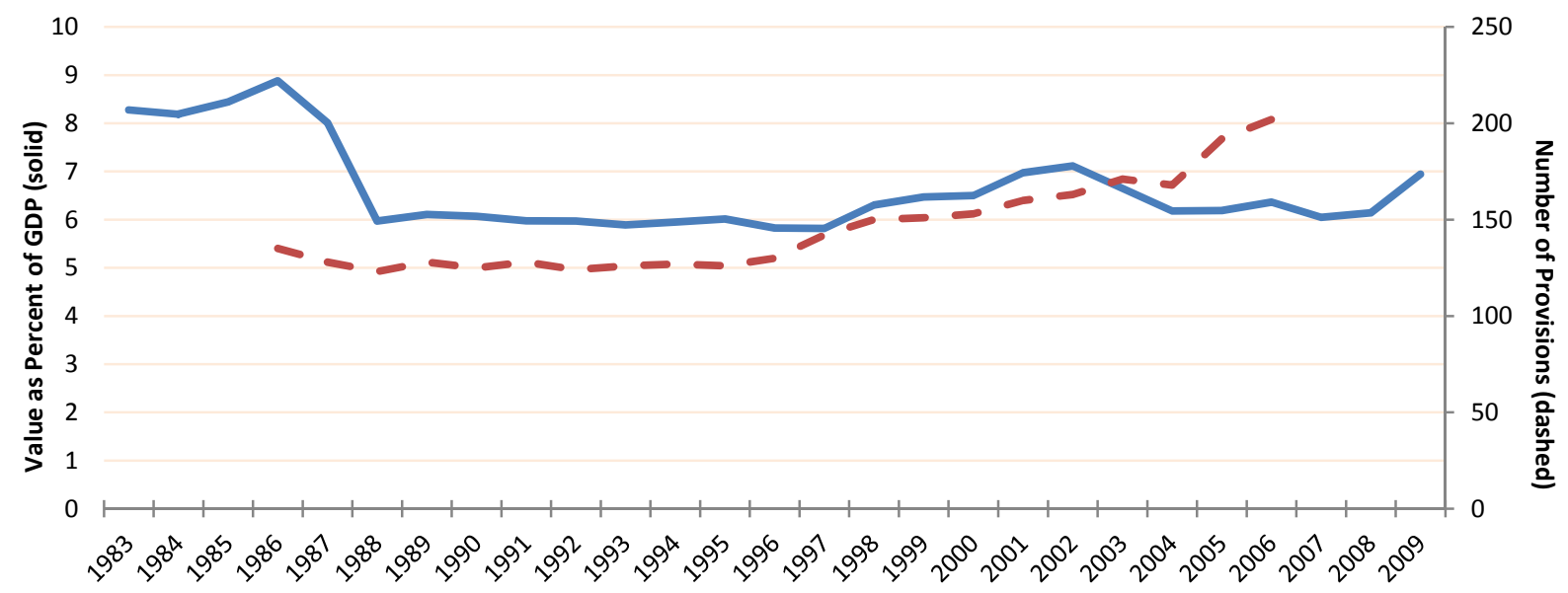

Source: For tax expenditures as percent of GDP, GAO analysis of OMB, Analytical Perspectives, Budget of the United States Government, Fiscal Years 1985-2011; for count of provisions, Joint Committee on Taxation (annual tax expenditure compilations back to 1985), and author's calculations.

Moreover, the sheer number of tax expenditures has increased sharply since the enactment of the Tax Reform Act of 1986. The Joint Committee on Taxation (2011) estimated that there were 202 tax expenditures in 2007, a 50 percent increase from 1986, when there were 135. Some of this increase was due to a change in the way the JCT compiled tax expenditures. (Buckley 2011) So the specific estimates should be taken with a large grain of salt, but there's no doubt that the number increased fairly dramatically. However, Buckley also points out that many of the largest tax expenditures have been in the tax code for a very long time and survived the massive tax reform enacted in 1986, suggesting that there is little political will to revise these programs.

Tax expenditures are large relative to other spending. (Table 1). Income tax expenditures will amount to about $\$ 1.2$ trillion in fiscal year 2011 based on US Treasury estimates. That is significantly larger than nondefense or defense discretionary spending. Tax expenditures would roughly equal total discretionary spending were it not for the extra outlays authorized in an effort to boost the economy out of recession. Overall, income tax expenditures are one-quarter of total spending, or about 8 percent of GDP. Put another way, excluding income tax expenditures causes spending to be about one-third less than it would be if tax expenditures were included in in the total. 
Table 1. Income Tax Expenditures Compared with Explicit Spending, FY2011

\begin{tabular}{|l|c|c|l|l|c|} 
& $\begin{array}{c}\text { Income Tax } \\
\text { Expenditures }\end{array}$ & Mandatory & Discretionary & Defense & $\begin{array}{c}\text { Non- } \\
\text { defense }\end{array}$ \\
\hline \$ Billions & 1,177 & 2,165 & 1,415 & 744 & 671 \\
\hline $\begin{array}{l}\text { Percent of total } \\
\text { spending }\end{array}$ & 24.7 & 45.5 & 29.7 & 15.6 & 14.1 \\
\hline$\%$ of GDP & 7.6 & 14.0 & 9.1 & 4.8 & 4.3 \\
\hline
\end{tabular}

Source: Budget of the United States, FY2011, and authors' calculations

Income tax expenditures are also large relative to tax collections (Table 2). In 2011, they exceed the individual income tax, which is the largest single source of revenue. This is somewhat anomalous because the recession cut income tax revenues and temporarily increased the number of tax expenditures. Eliminating income tax expenditures could allow income tax rates to be cut by about half with no loss of net tax revenues, could eliminate all or most of projected budget deficits for the next 20 years, or could finance a combination of rate reduction and deficit reductions. ${ }^{5}$ This was the approach of President Obama's debt reduction commission. (National Commission on Fiscal Responsibility and Reform, 2010)

Table 2. Income Tax Expenditures Compared with Explicit Taxes, FY2011

\begin{tabular}{|l|l|l|l|l|c|} 
& $\begin{array}{c}\text { Income Tax } \\
\text { Expenditures }\end{array}$ & $\begin{array}{c}\text { Net Individual } \\
\text { Income Tax }\end{array}$ & $\begin{array}{c}\text { Corporate } \\
\text { Income Tax }\end{array}$ & $\begin{array}{c}\text { Payroll } \\
\text { Tax }\end{array}$ & Other \\
\hline \$ Billions & 1,177 & 1,121 & 297 & 935 & 214 \\
\hline $\begin{array}{l}\text { Percent of total } \\
\text { revenues }\end{array}$ & 31.4 & 29.9 & 7.9 & 25.0 & 5.7 \\
\hline$\%$ of GDP & 7.6 & 7.2 & 1.9 & 6.0 & 1.4 \\
\hline
\end{tabular}

While the relative importance of tax expenditures depends on income tax rates, and thus the magnitude has waxed and waned somewhat with changes in rates, overall they have remained a

\footnotetext{
${ }^{5}$ Buckley (2011) expresses deep skepticism about such statements about the effect of eliminating all tax expenditures on net tax collections. First, he argues that eliminating all tax expenditures is not politically feasible. Second, he believes that behavioral responses to eliminating tax expenditures would causes revenues to fall far short of the static tax expenditure estimates. He's probably right about political feasibility, but that is not relevant to discussions about the opportunity cost of tax expenditures. As for the effect of a wholesale elimination of tax expenditures on tax avoidance, we believe that is a more open question. On the one hand, eliminating individual tax subsidies would certainly create incentives for the kind of avoidance response that Buckley chronicles. On the other, eliminating large numbers of tax expenditures would reduce the avenues available for tax avoidance. That is, hiding income from the tax collectors would be much more difficult if all or most of the explicit tax loopholes were eliminated. Nonetheless, it is clear that there is tremendous uncertainty about the revenue potential from eliminating all tax expenditures.
} 
significant component of overall spending (Figure 2). Meanwhile, mandatory programs have been inexorably growing. Defense has also proven difficult to control.

\section{Figure 2. Shares of Total Non-Interest Spending, Including Tax Expenditures, FY 1982-2015}

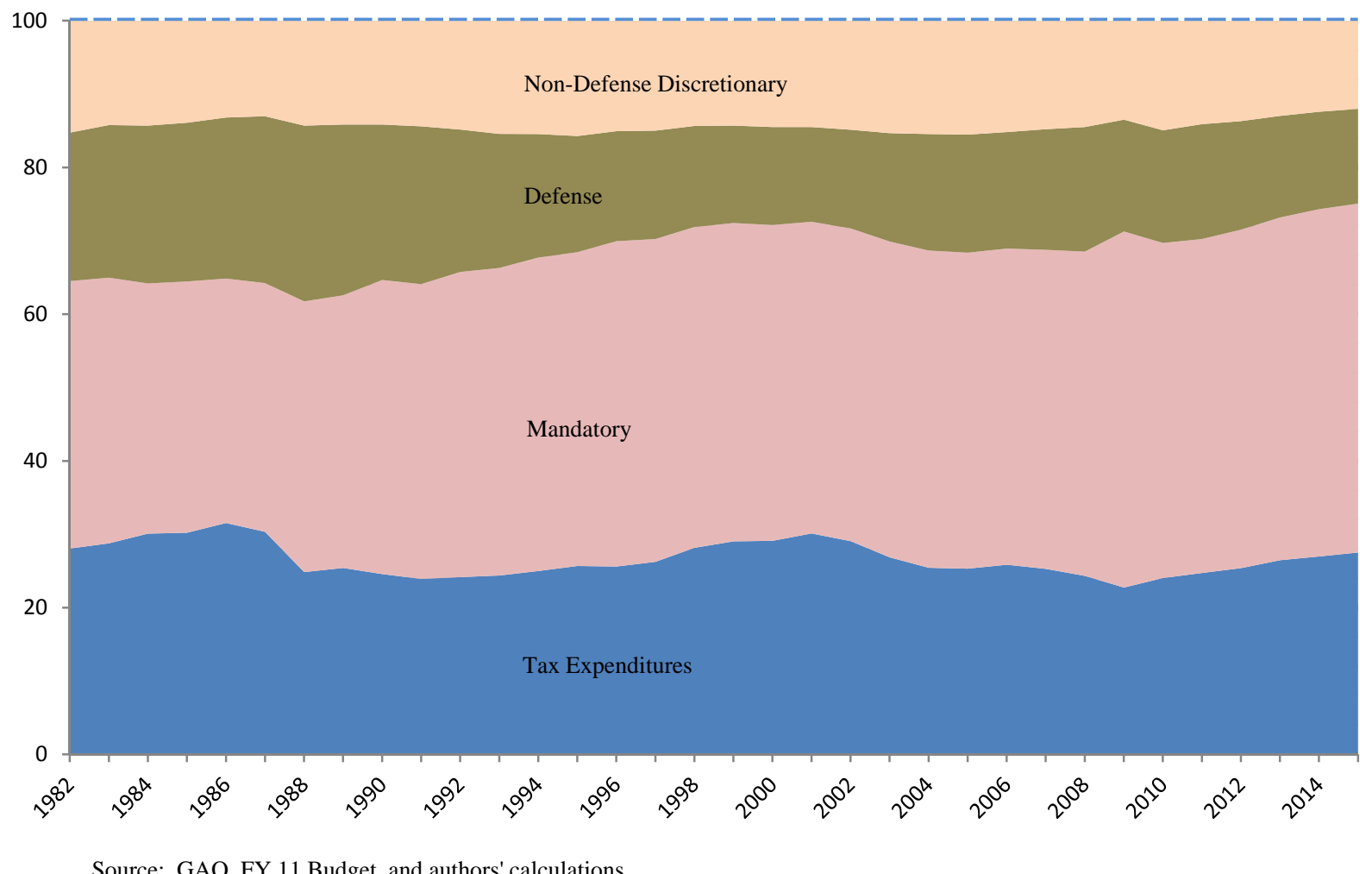

Source: GAO, FY 11 Budget, and authors' calculations.

\subsection{Issues in measuring tax expenditures}

A number of issues arise in measuring tax expenditures. ${ }^{6}$ To start, it is important to note that, by convention, a tax expenditure estimate is not a revenue estimate. Instead, it reflects the amount by which tax liability is reduced due to a particular tax provision. The estimate does not

\footnotetext{
${ }^{6}$ Shaviro (2004) raises a more fundamental point, arguing that taxes and spending are both meaningless concepts. Shaviro believes that programs on both sides of the ledger should be characterized based on whether they have primarily allocative roles or distributional roles. So a road construction program or the low-income housing credit are primarily allocative in nature - that is, redirecting resources to particular economic activities — whereas TANF or the EITC are primarily distributional. Shaviro, however, also recognized that the characterization of programs as "tax" or "spending" matter when political actors view the terms as meaningful. While intriguing, we view these issues as beyond the scope of this paper.
} 
include any behavioral response, which would be incorporated in a revenue estimate. Thus, for example, if the American opportunity tax credit—a tax credit for the first two years of postsecondary education —-were eliminated, many taxpayers who would have used that credit would instead opt for the less generous lifetime learning tax credit or other tax subsidies aimed at higher education. In consequence, the revenue savings to the Treasury would be only a fraction of the amount of American opportunity tax credits allowed. ${ }^{7}$

In addition, government estimates of tax expenditures do not account for losses in tax revenues from other revenue sources, most notably payroll taxes. For example, Joint Committee on Taxation (2008) estimated that the loss in payroll tax revenues from the tax exclusion for employer contributions to health insurance - the largest tax expenditure in 2011—is about twothirds of the income tax revenue loss alone. Thus, the total income plus payroll tax expenditure could be about $\$ 300$ billion compared with the estimate for the income tax expenditure alone of $\$ 177$ billion. (See Table 3.)

Table 3. Largest Tax Expenditures in FY 2011, In Billions of Dollars ${ }^{*}$

\begin{tabular}{|l|l|l|}
\hline 1 & Exclusion for employer-sponsored health insurance & Amount \\
\hline 2 & Mortgage interest deduction & 177.0 \\
\hline 3 & $401(\mathrm{k})$ plans & 67.1 \\
\hline 4 & Deduction for state and local taxes other than property taxes & 46.5 \\
\hline 5 & Step-up basis of capital gains at death & 44.5 \\
\hline 6 & Lower rate on capital gains & 44.3 \\
\hline 7 & Charitable deduction (other than education and health) & 43.9 \\
\hline 8 & Pensions (defined benefit) & 44.6 \\
\hline 9 & Exclusion of net imputed rental income & 37.6 \\
\hline 10 & Capital gains exclusion on home sales & 31.3 \\
\hline Note: Provisions are ranked based on 5-year total cost, FY 2011-2015. \\
\hline Source: US Budget, Analytical Perspectives, FY2011
\end{tabular}

Another apparent problem in attempting to gauge the importance of tax expenditures over time is that the cost of a group of tax expenditures is likely to differ from the sum of the individual estimates. For example, the cost of the deduction for home mortgage interest - the

\footnotetext{
${ }^{7}$ The same problem could occur in assessing outlays on explicit spending programs. For example, if the government were to eliminate Pell grants, which subsidize higher education, outlays for student loans could increase.
} 
second largest tax expenditure on Table 3-and the deduction for state and local taxes — the sixth largest — could be less than the sum of the two estimates. If either tax preference were eliminated, fewer taxpayers would itemize deductions, making the value of the second tax preference significantly smaller. ${ }^{8}$ However, Burman, Toder, and Geissler (2007) estimated that the overall cost of all individual tax expenditures is larger than the sum of the individual tax expenditures by about 6 percent. This occurs primarily because eliminating tax expenditures pushes some taxpayers into higher marginal tax brackets, which raises the value of remaining tax expenditures.

The Century Foundation Working Group on Tax Expenditures, a bipartisan group convened to evaluate current tax expenditures and make recommendations about how to improve monitoring and reporting, recommended a number of changes in the way tax expenditure information is reported. (Toder, Wasow, and Ettlinger, 2002) These include: annual estimates of the cost of all tax expenditures together and grouped by budget category; historical estimates of total tax expenditures based on a consistent methodology; and detailed information about the distribution of tax benefits as well as an assessment of how well the tax expenditures work.

\subsubsection{The problem of baseline}

The most serious challenge in measuring tax expenditures is in defining the "normal income tax.” Surrey and McDaniel (1985) argue that it should be a comprehensive Haig-Simons measure of income with adjustments to reflect problems of administration. As vague as that guideline is, the actual choice is even more nebulous. Surrey and McDaniel are agnostic about fundamental issues, such as whether the normal income tax should be indexed for inflation. Their basic view is that a fixed relatively comprehensive baseline should be chosen and it would serve as a useful measuring rod against which to gauge progress or lack thereof in improving the tax system.

\footnotetext{
${ }^{8}$ Taxpayers can take advantage of itemized deductions only to the extent that the total of all those deductions exceeds a standard deduction, which varies by filing status. Almost two thirds of tax returns in 2008 could not benefit from the deduction for charity, for example, because their deductible expenses were less than the standard deduction. (Internal Revenue Service 2010)
} 
There are some peculiar consequences of this approach. Expensing and accelerated depreciation of investments are treated as tax expenditures, whereas the taxation of capital gains on a realization basis, rather than as they accrue, is treated as part of the normal tax. ${ }^{9}$ Those provisions all convey tax benefits through a similar mechanism - taking advantage of the time value of money. Accelerating deductions and deferring income are two sides of the same taxminimization strategy, but only the deduction is counted as a tax expenditure. An even more stark contrast is with the treatment of savings bonds, on which the interest income is deferred until the bond is cashed in, which is identical to the treatment of capital gains. But the former is considered a tax expenditure, because accrual taxation of bond interest is straightforward (and the norm for most bonds), whereas accrual taxation of gains is not.

The normal income tax contains a classical corporate income tax with no offset for double taxation, even though corporate income would only be taxed once, on an accrual basis at the shareholder's tax rate under an ideal income tax. Under an economic income baseline, the taxation of dividends (as well as part of the tax on capital gains) would be a negative tax expenditure. $^{10}$

There are also issues about the treatment of what Surrey and McDaniel (1985) called "structural provisions," which he did not consider tax expenditures. Personal exemptions, for example, are identified as structural elements even though they are essentially subsidies based on family size - the deduction counterpart to the child tax credit, which is considered a tax expenditure. In addition, some commentators have argued that the normal tax should be a flatrate tax, in which case progressive tax rates should be considered tax expenditures. ${ }^{11}$ Indeed, the

\footnotetext{
${ }^{9}$ Haig-Simons income would include accrued capital gains, but the normal tax measures capital gains on a realization basis. Three factors drove this decision: historical precedent (gains have always been taxed for most individuals on a realization basis); the widely held belief that accrued but unrealized gains are not income; and the administrative difficulty of taxing gains when the sale price is not observable. Surrey and McDaniel (1985) seem ambivalent on this choice, deeming it as appropriate as of 1985, but one that should be reexamined over time.

${ }^{10}$ However, it is also true that many corporations pay little or no tax. In those cases, dividend and capital gains taxation may come closer to the tax burden under an integrated corporate tax. (Burman 2003) So the actual size and sign of the tax expenditure attributable to dividends and capital gains taxation relative to an economic income baseline is unclear.

${ }^{11}$ In another inconsistency, the lower tax rate that applies to small firms is considered a corporate income tax expenditure.
} 
current progressive rate structure could be mimicked by a flat-rate tax with a credit that corresponds to the savings from progressive rates. ${ }^{12}$ If the benefit of progressive tax rates were considered a tax expenditure, it would be the largest one in the tax code, by far. ${ }^{13}$

The most contentious issue is whether to define the normal tax as an income tax or a consumption tax. If the income tax is considered the norm, then savings tax incentives-such as tax-exemption for individual retirement accounts and pensions, and preferential tax rates for capital gains - are tax expenditures. The FY2003 Budget argued that the growing prevalence of tax-free savings vehicles might suggest a change in norm. "...[T]he growing presence of taxdeferred savings vehicles in the tax code suggests that these may today be part of the 'normal' income tax circa 2002." (US Office of Management and Budget, 2002, p. 96)

If a consumption tax is taken as the norm, then the taxation of interest and dividends are negative tax expenditures — that is, taxation in excess of the norm — and tax-exempt pensions and individual retirement accounts are part of the normal tax and not tax expenditures at all. Against this baseline, preferential tax rates on capital gains constitute a negative tax expenditure because they exceed the benchmark rate of zero. In contrast, against the income tax baseline, the failure to tax realized capital gains at full rates is the sixth largest tax expenditure. (See Table 3.)

People who favor an income tax also tend to favor the current method of measuring and displaying tax expenditures. Those who would prefer heavier reliance on consumption taxes would favor defining the normal tax as a broad-based consumption tax. ${ }^{14}$ Given that the actual income tax is a hybrid system containing many elements of income and consumption taxation, there is no obvious way to resolve this difference.

\footnotetext{
${ }^{12}$ For example, consider a very simple progressive tax system where the first $\$ 50,000$ of taxable income is taxed at a 10 -percent rate and income above that level is taxed at a 25-percent rate. Alternatively, all income could be taxed at a flat 25 percent, with a moderate-income family support credit (MIFSC) equal to 15 percent of income up to a maximum of $\$ 7,500$ (15 percent of \$50,000). Presumably the MIFSC would be treated as a tax expenditure under current rules, even though the benefit of the 10-percent rate bracket is not considered a tax expenditure.

${ }^{13}$ A very rough calculation suggests that, in tax year 2008, individual income tax before credits would have been about $\$ 900$ billion higher if all taxed at the top statutory tax rate of 35 percent (before accounting for additional tax avoidance).

${ }^{14}$ Indeed, economist Bruce Bartlett (2001) argued that using an income tax baseline creates a “...bias in favor of liberal tax policy."
} 
One option would be to consider only the tax expenditures that would be the same against any baseline. About half of the items in Table 3 are in that category. There are issues involved in excluding savings tax preferences, however. Their benefit is most skewed towards those with higher incomes (the main justification for retaining an income tax is that taxing saving increases overall progressivity). And excluding savings tax breaks might create a bias in favor of moving to a consumption tax, which might create an obstacle to bipartisan agreement.

Even those who favor a consumption tax could find useful information in the current tax expenditure tabulations. A hybrid income-consumption tax, as we have in the United States, may actually do more to impair national savings than a pure income tax, because of the nonneutralities among different kinds of saving and investment. The tax expenditure list provides at least a crude measure of these non-neutralities, insofar as it shows that particular industries or forms of saving benefit more than others.

\subsection{The implication of ignoring tax expenditures in the budget}

Incorporating tax expenditures into the budget would increase budget transparency. Kleinbard (2010) recommends that open-ended tax expenditures (most of them) should be treated as mandatory spending while those few tax expenditures that are subject to appropriation limits (like the low-income housing credit) be included in the budget with discretionary spending. But currently, tax expenditures are simply subtracted from overall tax revenues and excluded from spending totals altogether. New tax expenditures reduce reported revenues while leaving reported spending unchanged when, in fact, they should be added to spending while leaving total revenues unchanged.

Why does this matter? For measuring the deficit, it doesn't. Since the deficit is spending minus revenues, the difference will be the same whether tax expenditures are recorded as positive spending or negative revenues. If policymakers and the public were perfectly rational and fully informed, presumably budget choices would be unaffected by the accounting.

In fact, we believe that current accounting for tax expenditures introduces substantial biases. Taxpayers may like government spending programs, but dislike paying for them. In that light, an increase in explicit spending and higher taxes now or in the future is much less attractive than an increase in spending that masquerades as a "tax cut"—-taxpayers get benefits along with the 
illusion that they are costless. Tax expenditures make government appear smaller while providing more benefits. This creates the illusion of extreme policy efficiency when, in fact, tax expenditures are often less efficient than alternative cash programs.

\subsubsection{A simple model of tax expenditure distortions}

To illustrate how failure to explicitly account for tax expenditures in tax and spending totals might bias budget decisions, consider this stylized model of political choice. Policy makers choose taxes, cash outlays, and tax expenditures to maximize votes, which are a function of the representative (or median) voter's preferences. The representative voter values cash outlay programs and tax expenditures. She benefits from new roads, national defense, courts, Medicare, Social Security, etc., as well as the tax deductions, credits, and exclusions that apply to her. However, she understands that at least a portion of current spending will come at the expense of current or future consumption of private goods, which she also values. She fully understands the cost of cash outlays, but may underestimate the burden attributable to tax expenditures because they are not included in published tax or spending totals. In others words, taxes and spending appear smaller because tax expenditures are excluded.

One way to think of this model is in the context of the "fiscal illusion" framework employed in the public choice literature. For example, according to Ura and Stocker (2011), "Revenue collection strategies which obscure the cost of government should interfere with citizens' ability to effectively evaluate government services and programs. When benefits remain evident while costs are hidden, citizens will demand additional services and benefits without regard to costs, creating electoral pressure on officeholders to expand the scope of government activity.” Ura and Stocker use this framework to explain why underestimating the cost of deficits could lead to larger government, but the same framework explains why the cost of tax expenditures might be misperceived.

Define the amount of cash outlays as $X$ and tax expenditures as $E$, and the resultant perceived tax burden (present or future) as $T$. Define a fiscal illusion parameter, $\alpha$, which corresponds to the fraction of tax expenditures that voters disregard in assessing tax burdens. $\alpha=1$ corresponds to full illusion, where tax expenditures are netted out of spending and taxes and appear to be free; $\alpha=0$ would correspond to full transparency (where tax expenditures are treated the same as cash 
outlays). We posit that voters perceive only part of the burden of tax expenditures - that is, $0<\alpha<1$.

The policymaker's problem is:

$$
\begin{gathered}
\max _{X, E} V(X, E, \widehat{T}) \\
\text { Subject to } \widehat{T}=X+(1-\alpha) E
\end{gathered}
$$

$V$ is a vote function. $\hat{T}$ is the portion of tax expenditures that voters understand they have to pay for, either now or later. ${ }^{15}$ We assume that $V_{1}>0, V_{2}>0$, and $V_{3}<0$. That is, voters value cash and tax expenditures and are averse to perceived tax burden. Assume further that $V_{i i}<0$ for all $i$. Interpreting $V$ as a kind of utility of government function, this means that the median voter has diminishing marginal utility for expenditures and increasing marginal aversion to perceived taxes. Defining the Lagrangian, $L$, in the usual way and maximizing with respect to $X$, $E$, and $\widehat{T}$ yields the following first-order conditions (assuming an interior solution):

$$
\begin{aligned}
& \frac{\partial L}{\partial X}=V_{1}-\lambda=0 \\
& \frac{\partial V}{\partial E}=V_{2}-\lambda(1-\alpha)=0 \\
& \frac{\partial V}{\partial \hat{T}}=V_{3}+\lambda=0 \\
& \frac{\partial V}{\partial \lambda}=\widehat{T}-X-(1-\alpha) E=0
\end{aligned}
$$

If taxpayers are well informed, $\alpha=0$, and $\widehat{T}=X+E=T$. Perceived tax burden equals actual tax burden. The first-order conditions produce the intuitive result:

\footnotetext{
15 In terms of the utility function of the representative consumer or median voter, the consumer's problem (assuming non-distorting lump-sum taxation) is $\max \mathrm{U}(\mathrm{X}, \mathrm{E}, \mathrm{c})$, s.t. $c=y-\theta \widehat{T}$, where c is consumption of a composite private good, y is (exogenous) income, and $\theta$ is that voter's share of the costs of government. Substituting the budget constraint into the utility function yields $U(X, E, y-\theta \widehat{T})$. Given $y$ and $\theta$ are fixed, by assumption, this can be written as $V(X, E, \widehat{T})$, a positive function of $X$ and $E$, and a negative function of $\widehat{T}$. This is the vote function.
} 


$$
V_{1}=V_{2}=-V_{3}
$$

That is, the marginal utility of cash and tax expenditures are equal to each other and to the marginal disutility of taxes. ${ }^{16}$

Allowing $\alpha>0$, we can write the first-order condition in terms of a marginal rate of substitution (holding $V$ constant),

$$
-\left.\frac{\partial E}{\partial X}\right|_{V=\text { constant }}=\frac{1}{1-\alpha}
$$

Effectively, fiscal illusion causes voters to misperceive the price of $E$ as less than 1. The result is an unambiguous increase in $E$ and government spending and actual taxes or deficits. Spending on cash outlays can increase, decrease, or stay the same depending on the degree of substitutability between $X$ and $E$.

Figure 3 illustrates the case where the elasticity of substitution between $X$ and $E$, $\sigma$, is 1 (i.e., Cobb-Douglas utility function). Assuming constant cost per unit of producing $X$ and $E$, fiscal illusion amounts to a reduction in the price of $E$ from 1 to 1- $\alpha$. If $X_{0}^{*}, E_{0}^{*}$ solve the policymaker's maximization problem when $\alpha=0, \widehat{T}=X_{0}^{*}+E_{0}^{*}$, then introducing fiscal illusion rotates the budget constraint clockwise. Holding $\widehat{T}$ constant, the new budget constraint is shown on the Figure. In the special case where $\sigma=1, X^{*}$ does not change $\left(X_{1}^{*}=X_{0}^{*}\right)$, while $E_{1}^{*}=\frac{E_{0}^{*}}{1-\alpha} . X_{1}^{*}, E_{1}^{*}$ still solve the first-order conditions given $\alpha$.

\footnotetext{
${ }^{16}$ Note that this framework could subsume the deficit illusion analyzed by Ura and Socker (2011). In that context, $V_{3}$ becomes too small, implying large amounts of cash and tax expenditures because people don't fully perceive how they translate into current or future taxes.
} 
Figure 3. Effect of Fiscal Illusion on Cash Outlays and Tax Expenditures Constant Elasticity of Substitution, Linear Cost Function

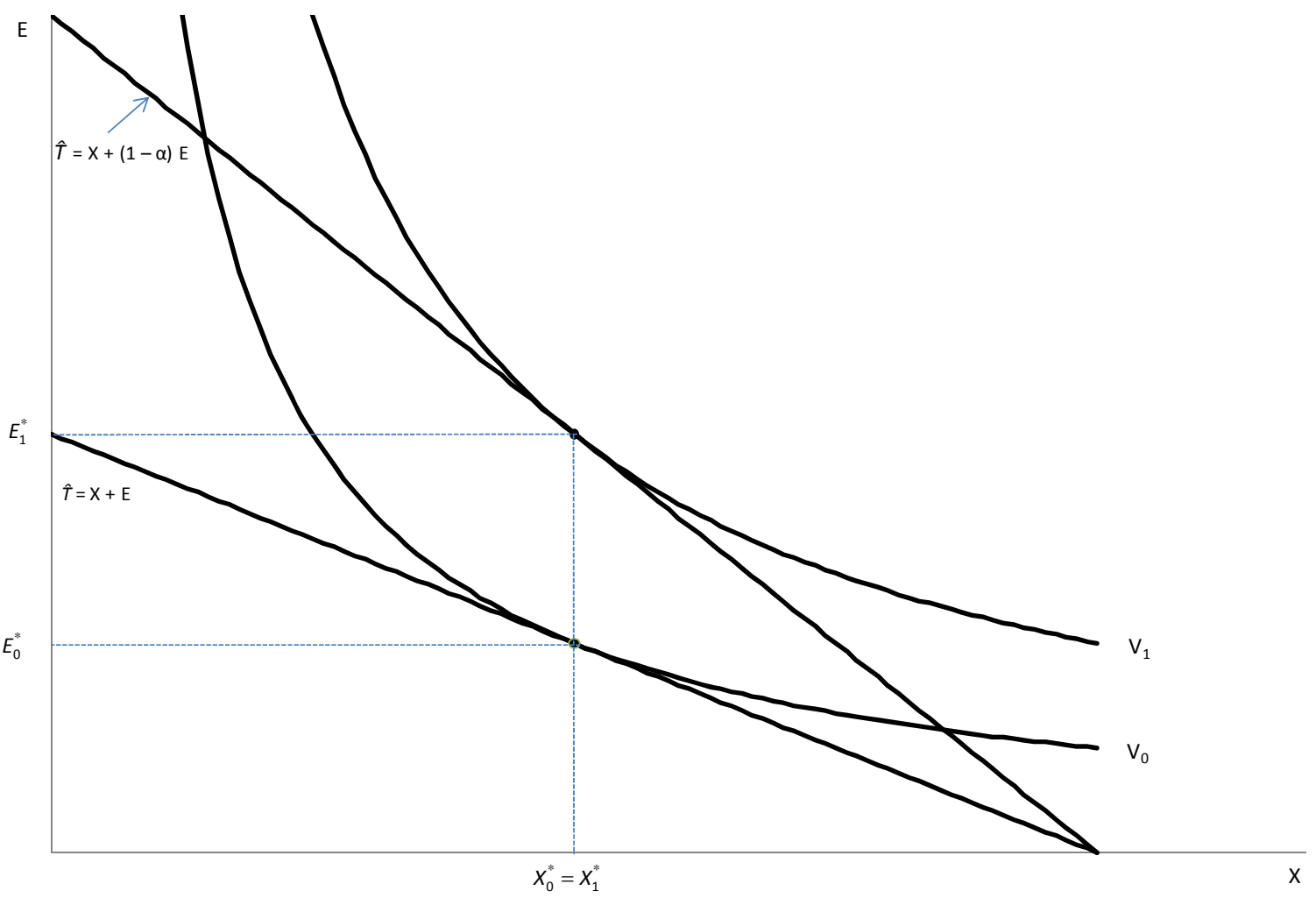

In this special case, cash outlays remain unchanged, tax expenditures increase, and the size of government increases.

Figure 4 shows the situation in the case where $X$ and $E$ are substitutes. ${ }^{17}$ In this case, starting from the optimum when $\alpha=0$, imposing fiscal solution again rotates the budget constraint clockwise. The vote maximum subject to the new constraint, at point $\mathrm{B}$, does not solve the optimization problem because $X<X_{0}^{*}$ (as $E$ is substituted for $X$ at the lower price). Lower $X$ raises $V_{1}$, implying that at the new optimum, $\widehat{T}$ will rise. So the budget constraint shifts outward. At the new optimum, $\mathrm{C}, E_{1}^{*}>\frac{E_{0}^{*}}{1-\alpha}$. Total spending increases even more than in the $\sigma=1$ case.

\footnotetext{
17 The graphs show CES functions. $\sigma=1.7$ for the substitute case. For the complement case shown below, $\sigma=0.6$.
} 


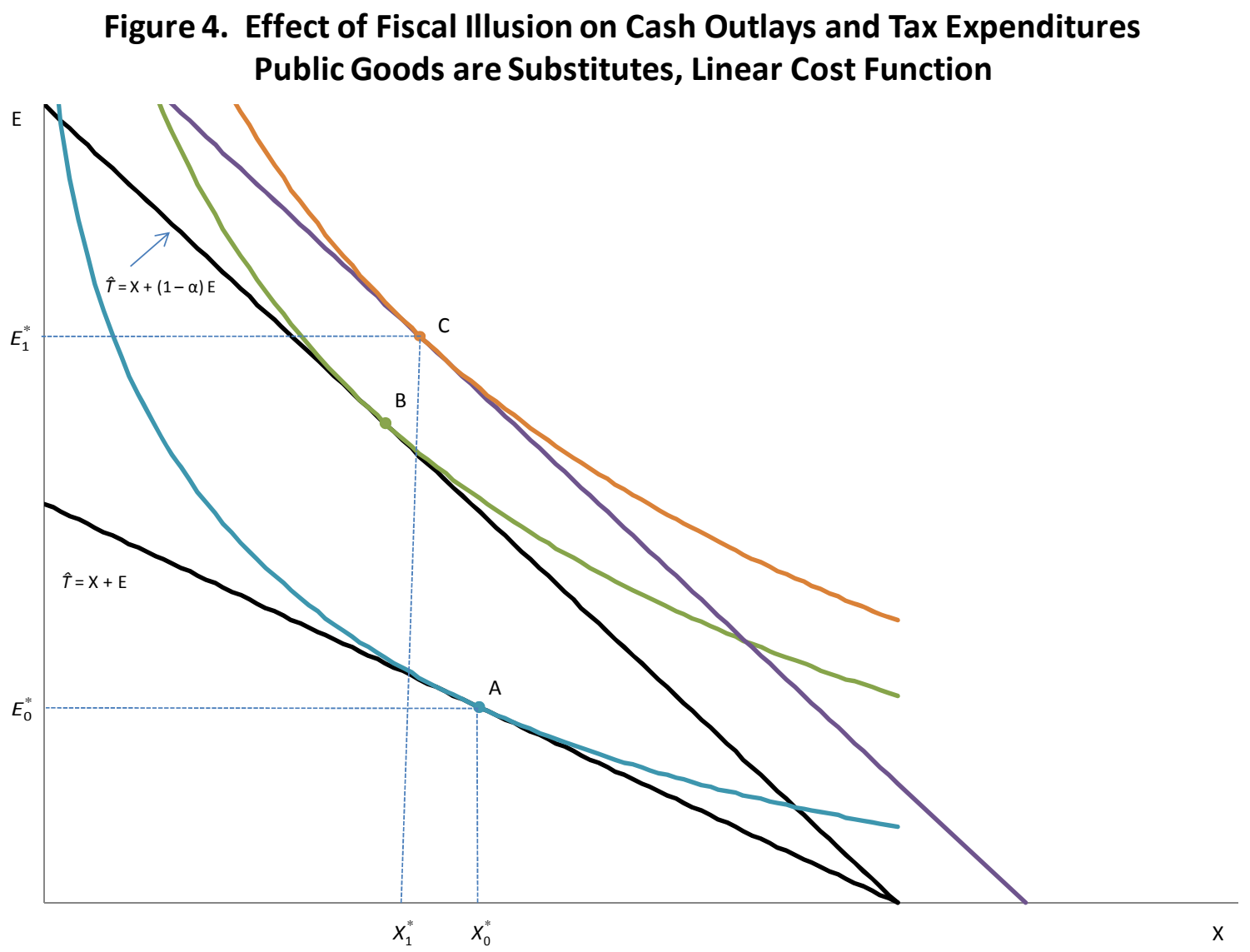

It is clear in this model that fiscal illusion introduces an inefficiently large government and an inefficient allocation of public spending in favor of tax expenditures. However, the inefficiency could be even larger if the cost per unit of producing $X$ and $E$ increase with spending. In particular, if some programs are natural to run through program agencies and others through the tax code, then shifting more spending through the tax code (or cash outlays) starting from the optimal allocation will introduce production inefficiency as well as lost utility to consumers (voters).

We can extend the model above to account for increasing costs of production of $X$ and $E$. To simplify, assume that the costs are separable and that the perceived cost of government is

$$
\widehat{T}=C_{x}(X)+C_{E}(E)(1-\alpha)
$$

where $C_{x}$ and $C_{E}$ satisfy $C^{\prime}>0$ and $C^{\prime \prime} \geq 0$. Substituting this budget constraint into the optimization problem yields the following first-order conditions: 


$$
\begin{aligned}
& \frac{\partial L}{\partial X}=V_{1}-\lambda C_{X}^{\prime}=0 \\
& \frac{\partial V}{\partial E}=V_{2}-\lambda(1-\alpha) C_{E}^{\prime}=0 \\
& \frac{\partial V}{\partial \hat{T}}=V_{3}+\lambda=0 \\
& \frac{\partial V}{\partial \lambda}=\widehat{T}-C_{X}(X)-C_{E}(E)(1-\alpha)=0
\end{aligned}
$$

The optimum now sets marginal utility equal to marginal perceived cost. And instead of equating the marginal rate of substitution and $(1-\alpha)$, the optimum equalizes MRS and $(1-\alpha)$ times marginal rate of transformation.

$$
\mathrm{MRS}=V_{1} / V_{2}=\frac{1}{1-\alpha} \frac{C_{X}^{\prime}}{C_{E}^{\prime}}=\frac{\mathrm{MRT}}{1-\alpha}
$$

The three panels of Figure 5 illustrate the effects of fiscal illusion on the determination of $X$ and $E$ under various degrees of substitutability in the vote function. The qualitative conclusions do not change from the constant cost case, however, the degree of shifting from $X$ to $E$ declines. As in the linear case, $E$ and overall spending will tend to rise most when $X$ and $E$ are substitutes. $E$ does not increase as much as in the linear case because the cost per unit of producing $E$ increases as more spending is channeled through tax expenditures. When $X$ and $E$ are complements, $X$ will tend to rise while the increase in $E$ will be smaller. ${ }^{18}$ In the latter case, the overall size of government does not grow as much. But, that is only because the perceived cost of increasing $E$ increases when $X$ must increase as well.

\footnotetext{
${ }^{18}$ In the illustrations, $X$ remains fixed when $\sigma=1$, but that is an artifact of using very simple quadratic functions $\left(\mathrm{C}(\mathrm{x})=\mathrm{x}^{2}\right)$ to draw the isocost curves. In that special case, $M R S=k \frac{E}{X}$ and $M R T=\frac{1}{1-\alpha} \frac{X}{E}$, implying that at the optimum, $X^{2}=(1-\alpha) k E^{2}$. If $E_{0}^{*}$ and $X_{0}^{*}$ solve the first-order conditions for $\alpha=0$, then the first two marginal conditions yield $E_{\alpha}=\sqrt{1-\alpha} E_{0}^{*}$ and $X_{\alpha}=X_{0}^{*}$, which leaves $\widehat{T}$ unchanged. Thus, this is the new optimum (given $\alpha$ ). This result, however, does not generalize for other cost functions.
} 
Figure 5. First-Order Effect of Fiscal Illusion on Cash Outlays and Tax Expenditures with Increasing Costs of Production (Holding $\widehat{T}$ Constant)
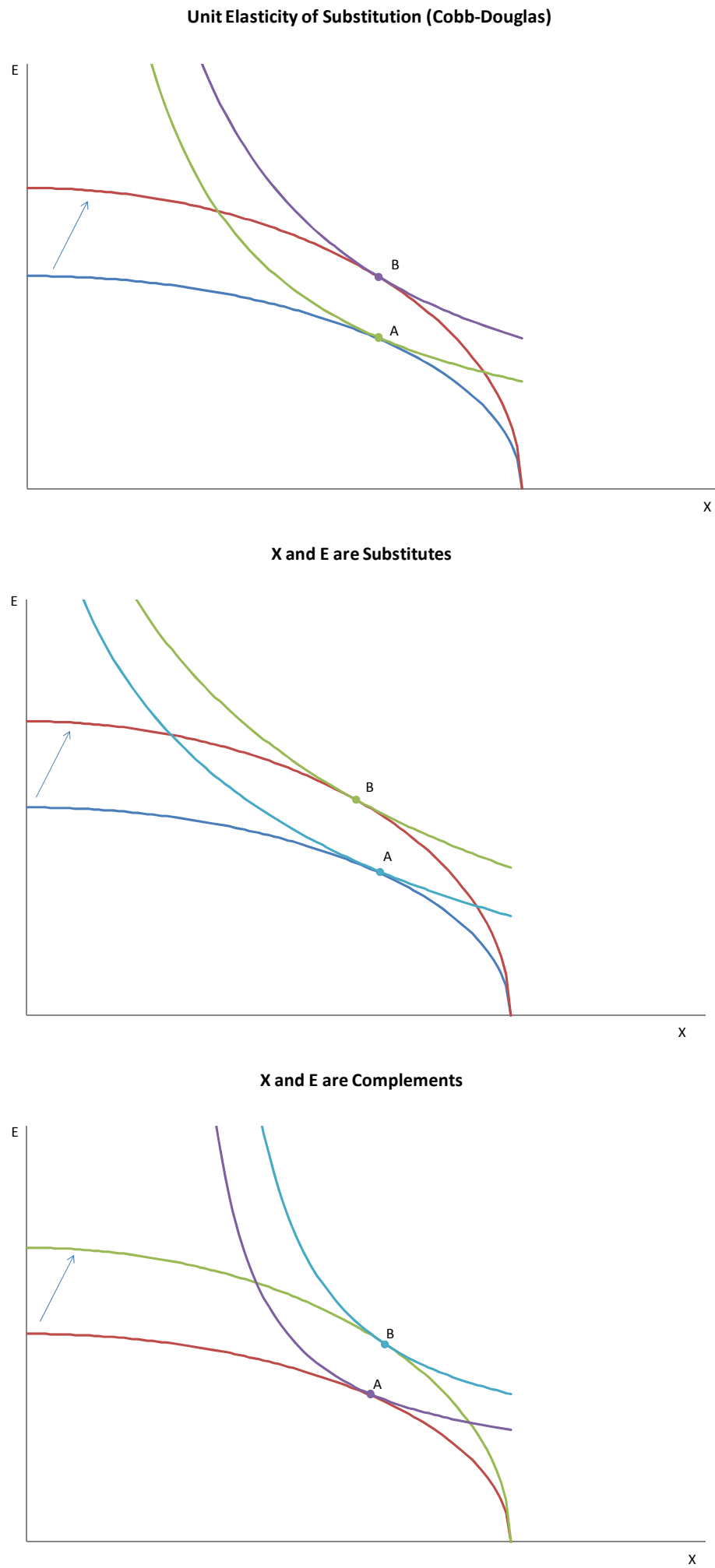
Here are the general conclusions that come from this model in the presence of fiscal illusion. Voters' misperceptions about the cost of tax expenditures result in too much spending through tax expenditures and larger government than would occur if voters were fully informed. If tax expenditures and cash outlays are complements, there could also be more outlays than would arise with fully informed voters. In the more likely case where voters perceive tax expenditures and cash outlays as substitutes, cash outlays will tend to decline, but overall spending increases even more because voters perceive the drop in cash outlays as a drop in the size of government and believe that they can afford even more public spending. Allowing for the possibility that the per unit cost of producing tax expenditures and cash outlays increases reduces the increase in the amount of tax expenditures, because tax expenditures become more costly as more and more government services are produced that way. In addition to the inefficient allocation of services from the voters' perspective, there is also a production inefficiency. That is, the cost of producing government services per unit increases relative to the optimum in which voters are fully informed.

Obviously, this model oversimplifies reality. For example, the degree of fiscal illusion may decline as $E$ increases and marginal tax rates or deficits rise. But the implication of the model comports generally with intuition. Excluding tax expenditures from budget aggregates increases taxes (current or future), overall spending, and tax expenditures. Government is not only too big relative to the optimal size, but the allocation of spending between cash outlays and tax expenditures is inefficient. Making taxes seem artificially low may also cause the level of cash outlays to increase compared with the efficient (full disclosure) case.

Beyond the implications for efficiency and the size of government, the miscounting of tax expenditures has implications for tax reform. For example, the president's National Commission on Fiscal Responsibility and Reform, co-chaired by Erskine Bowles and Alan Simpson, proposed eliminating most tax expenditures, significant spending cuts and reductions in marginal income tax rates. That proposal prompted a prominent conservative group to claim that the BowlesSimpson plan would violate a pledge many legislators had signed promising never to raise 
taxes. ${ }^{19}$ In fact, if properly accounted for, the Bowles-Simpson proposal would cut taxes significantly and make larger cuts in total spending than reported. ${ }^{20}$

\subsection{Potential bipartisan appeal of budgeting for tax expenditures}

Another argument against the tax expenditure concept is the notion that it assumes that all income belongs to the government unless government deigns to refund it in the form of tax breaks. Interestingly, neither this argument nor the concept of tax expenditure is a new one. Brooks (1986) reports that in 1863, William Gladstone, then a Tory member of the British parliament, railed against the exemption from income tax of charitable contributions. He complained that the charitable deduction would make no sense as a direct expenditure, conflicting as it would with efforts to bring “...the whole expenditure of the State...within the control, and under the eye, of the House of Commons. If this money is to be laid out upon what are called charities, why is that portion of the State expenditure to be altogether withdrawn from view... and to be so contrived that we shall know nothing of it, and have no control over it...?”21

The rebuttal from Sir Strafford Northcote would be familiar to modern critics of tax expenditures: “"The right hon. Gentleman, if he took $£ 5$ out of the pocket of a man with $£ 100$, put the case as if he gave the man $£ 95 .$. ,” (Brooks, 1985, p. 684) More than a century later, the Republican Vice Chairman of Congress’s Joint Economic Committee, Jim Saxton, complained that " $[\mathrm{t}]$ he tax expenditure concept relies heavily on a normative notion that shielding certain taxpayer income from taxation deprives government of its rightful revenues.” (Saxton 1999)

The irony of this aspect of the debate is that conservatives usually object to growth of government spending. Presumably it is relevant in evaluating spending on housing programs, for

\footnotetext{
${ }^{19}$ Americans for Tax Reform, which administers the "taxpayer protection pledge,” opined, "Simpson-Bowles is a massive tax hike masquerading as tax reform.” (Ellis 2010)

${ }^{20}$ In a February 17, Newshour interview with Judy Woodruff, Sen. Saxby Chambliss (R- Ga.) defended his work with Sen. Mark Warner (D-Va.) in support of the Bowles-Simpson recommendations as consistent with the ATR "no tax increase" pledge because the changes would lower tax rates as well as the deficit. He said that he and Warner are seeking to adopt changes that would "eliminate some of the tax expenditures ... and reduce taxes that every individual has to pay simply by reforming the tax code.” http://crackersquire.blogspot.com/2011/02/senschambliss-and-warner-discuss.html. Accessed March 25, 2011.

${ }^{21}$ Cited in Brooks (1985, pp. 683-684).
} 
example, to note that the largest new construction program is not financed by cash expenditures overseen by the Department of Housing and Urban Development, but the low-income housing credit. One of the largest cash assistance programs for low-income families is the earned income tax credit. And so on. All of these programs could be carried out with cash expenditures, and presumably fiscal conservatives would want to monitor their cost and effectiveness if they were thus transformed.

And, as discussed in the previous section, the misattribution of tax expenditures may cause overall government spending, taxes, and the deficit to be higher than they would otherwise be, and for government resources to be inefficiently allocated in favor of tax expenditures. The revenues lost to inefficient tax expenditures could otherwise be used to reduce the deficit or lower tax rates. Indeed, the Tax Reform Act of 1986, enacted two decades after the government began to produce estimates of tax expenditures, illustrates this trade-off. Top marginal tax rates for individuals were cut from 50 percent to 28 percent, and from 46 percent to 34 percent for corporations in a package that was designed to be revenue neutral. (Birnbaum and Murray, 1988) The dramatic rate reductions were financed entirely by eliminating or curtailing tax expenditures. $^{22}$ Millions of taxpayers were also removed from the tax rolls. All of the recent bipartisan tax reform proposals have used some of the revenue gained from eliminating tax expenditures to lower marginal income tax rates (and some for deficit reduction). ${ }^{23}$ They would cut taxes and spending (when tax expenditures are properly accounted for).

Reducing tax expenditures should appeal to liberals too. With the exception of the small number of refundable tax credits, tax expenditures tend to be middle- and upper-income entitlements. (Burman, Toder, and Geissler 2007) The privileged status of tax expenditures means that spending is skewed in favor of programs that favor the relatively well off. Efforts to reduce spending that ignore tax expenditures necessarily mean that the burden of deficit reduction will fall disproportionately on those with lower incomes.

\footnotetext{
22 There was also a shift of tax liability from individuals to corporations that some viewed as anti-growth. Nonetheless, eliminating tax expenditures made possible substantial tax rate cuts which most economists would view as efficiency-enhancing.

${ }^{23}$ See, e.g., National Commission on Fiscal Responsibility and Reform (2010) and Bipartisan Policy Center (2010).
} 
And controlling tax expenditures could have the added benefit of simplifying the tax system and making it more efficient by reducing the opportunities for tax sheltering. If some of the budget savings are used to cut marginal income tax rates, the efficiency gains would grow. Moreover, to the extent that the proliferation of tax expenditures fuels perceptions of unfairness, trimming them could enhance the integrity of the income tax.

In practice, the politics are much more complex. As noted, all of the budget reduction plans would cut tax expenditures, including the plan proposed by House Budget Committee Chairman, Paul Ryan (R-WI) and recently passed by the House of Representatives, and the framework laid out by President Obama (2011). A bipartisan group of 64 senators (32 from each party) sent a letter to President Obama urging that any debt reduction plan include “discretionary spending cuts, entitlement changes and tax reform. ${ }^{24}$ Neither Obama nor Ryan has specified which tax expenditures should be reduced or eliminated and Senator Ryan rejected the notion of cutting tax expenditures as a way to reduce the deficit (he'd instead use the savings to cut income tax rates), but all of the debt reduction plans recognize that substantial amounts of spending run through the tax code.

But there's still a lot of public skepticism about the concept of tax expenditures. Jon Stewart, host of the satirical Daily Show on Comedy Central, derided president Obama for referring to "spending reductions in the tax code." This provoked a Stewart rant: "What??? The tax code isn't where we spend. It's where we collect. ... You managed to talk about a tax hike as a spending reduction. Can we afford that and the royalty checks you'll have to send to George Orwell?” And Senator Orrin Hatch (R-Utah), Ranking Member of the Senate Finance Committee argued that tax expenditures and spending have fundamentally different effects on the size of government: "Reducing or eliminating a tax expenditure without lowering rates enough to reach a revenue neutral level will cause the size of the federal government to grow, while reducing or eliminating spending causes the size of the federal government to shrink.” (Hatch 2011)

\footnotetext{
${ }^{24}$ Letter available at: http://tinyurl.com/64senators.
} 


\section{Budgeting for Tax Expenditures}

As the previous section showed, the characterization of tax expenditures as tax reductions may bias policymakers to favor tax expenditures over more effective cash outlay programs or deficit reduction. Integrating tax expenditures explicitly into the existing federal budget process could reduce or eliminate that bias. Beyond simply increasing transparency, treating tax expenditures as spending could subject them to effective controls on overall spending as part of broader budget reform.

\subsection{Including Tax Expenditures in the Current Budget Process}

Spending through the tax code is currently off the budget table. Except for the refunded portion of refundable tax credits, which are shown as outlays, the cost of existing tax expenditures appear in the budget's summary tables only insofar as they affect net revenues.

Newly enacted tax expenditures are scored as tax cuts—reducing revenues and increasing the deficit. But tax expenditures are not limited by appropriations. Most are permanent parts of tax law and do not require periodic reconsideration or review. Growth in the year-to-year value of tax expenditures is included (as reductions) in budget baseline projections of revenues and requires no legislative action.

Tax expenditures share many features with mandatory spending: exemption from control by appropriations, permanent authorization, and automatic growth without further action by the Congress. However, mandatory spending is explicitly reported in the budget and in the functional totals. The exception is Social Security, which has been moved "off budget” through legislation. However, the effect of that re-classification has been diminished by the budget agencies’ practice of showing unified budget totals as the sum of both off-budget and on-budget sub-totals.

Tax expenditures and direct spending account for over 70 percent of all federal spending. Despite the dominance of tax expenditures and direct spending, there is nothing in the current process that forces an affirmative decision on the appropriate size of this spending now or in the planning period. 
Tax expenditures could be included in the budget by treating them as equivalent to other forms of mandatory spending. ${ }^{25}$ This might involve the following changes to current practice:

1. Add tax expenditures to the budget totals consistent with their transactional equivalence to a) levying taxes and b) refunding the tax to those who meet the criteria for receiving benefits.

2. Score the cost of new tax expenditures as increases in spending, rather than as a reduction in revenues

3. Tally tax expenditures in the Concurrent Budget Resolution's cap on total budget authority and outlays and allocated by function and to committee(s) of jurisdiction

4. Include tax expenditures in reconciliation instructions and omnibus legislation and subject them to points of order

5. Require the President to revise the budget accounts and functional allocations to include tax expenditures.

We elaborate on these steps below.

Add tax expenditures to summary budget totals. The current treatment of tax expenditures shows the net effect of tax expenditures on the deficit but fails to identify the amount of fiscal resources used in this way or the effect on outlays. Table 4 illustrates an alternative display of tax expenditures in the summary budget tables. Tax expenditures, as taxes levied and refunded, would not reduce total revenue but rather change its composition and increase budget outlays.

${ }^{25}$ The same principles also apply at the state level. Blumenthal, et al (2011) recently recommended that Minnesota fully integrate significant tax expenditures into the budget process and also subject all tax expenditures to review at least every eight years. The review would include an evaluation of cash outlay alternatives to the tax expenditure. After the review, the legislature would have to vote to continue the tax expenditure by a "sunset date" or the program would lapse. 


\section{Table 4. Example of Adding Tax Expenditures to Budget Totals}

Total revenues

Cash

Tax expenditures

Total outlays

Cash

Tax expenditures

Surplus (deficit)

Borrowing from the public
4.0

3.0

1.0

5.0

4.0

1.0

1.0

Note that current budgeting only shows cash revenues, outlays.

The alternative option clarifies both the size and nature of tax expenditures. It also reduces the current budgetary bias in favor of tax expenditures.

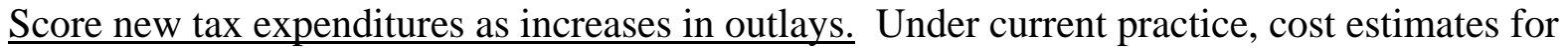
new legislation that increases or decreases tax expenditures report the effect on cash revenues and the deficit but show no effect on outlays. Consistent with the treatment of other spending, tax expenditure legislation would be scored with its outlay effects. Table 5 provides an example for legislation that increases tax expenditures.

Table 5. Scoring an Increase in Tax Expenditures

Change in total revenues

Cash $-0.1$

Tax expenditures

$+0.1$

Change in total outlays $+0.1$

Cash

0.0

Tax expenditures $+0.1$

Change in surplus (deficit)

Change in borrowing from the public

Note: Current scoring only shows the change in cash revenues and outlays. 
Include tax expenditures explicitly in the budget resolution's cap on total spending and the functional distribution tables. The budget resolution sets aggregate limits on new budget authority and outlays and distributes those sums across 20 budget functions, each with numerous sub-functions. ${ }^{26}$ In addition, though not specified in the resolution, those totals are allocated to each of the legislative committees of jurisdiction. These are referred to as Section 203 allocations for the section of the Budget Act that authorizes them. Discretionary appropriations are allocated to the appropriations committees and direct spending to the authorizing committees. These allocations constitute the legislative spending budgets for each committee.

Under current practice, tax expenditures are not allocated to functions or committees. They are tabulated by function, and shown in a report that supplements the budget data, but is not a part of it. Under comprehensive treatment, tax expenditures would be included in the budget resolution by function and sub-function and allocated to the committees of jurisdiction. That allocation could also reflect shared jurisdiction between authorizing and tax committees. Further, tax expenditures would be assigned to a new or existing budget account and all new accounts would be assigned to a budget sub-function. This change could promote trade-offs within tax expenditures and across tax expenditures and other forms of spending.

Add tax expenditures to the President's budget. To maintain consistency between the president's budget and Congressional practice, the executive budget would move tax expenditures from supplementary material into the budget accounts, functional distributions, and summary budget totals.

Moving tax expenditures into the budget and treating them as other forms of spending would be a step toward more comprehensive and transparent budgeting, but it is not a panacea. It does not guarantee tax reform or that inefficient tax expenditures would be converted into cash spending programs or eliminated. At best, it communicates more clearly and accurately the

\footnotetext{
${ }^{26}$ One of the functional spending categories, number 920, is the Allowances function. The Budget Act intended Congress to budget funds for uncertain spending on items such as natural disaster relief and recovery. Congress, however, has preferred the concept of emergency spending, which is "unplanned” and exempt from budget limits and controls. Some analysts have proposed dropping 920 since it is never used, leaving only 19 functional categories.
} 
nature, size, and cost of tax expenditures. It aims to provide equivalent information about tax expenditures and other forms of spending.

\subsection{Enforcement of Caps on Tax Expenditures}

A fundamental challenge in imposing caps on spending is that they require an effective enforcement mechanism. Even for cash outlays, experience with Gramm-Rudman-Hollins suggests that excessively harsh penalties, while theoretically plausible, are ineffective in practice. Policymakers will simply subvert enforcement mechanisms if the political cost of accepting the penalty is greater than the cost of dodging it.

One approach to enforcement would be to have an automatic fallback mechanism to achieve targets if Congress fails to meet the global caps. The Bowles-Simpson plan included a failsafe mechanism that combined sequesters and tax increases. The president has also proposed a trigger with across-the-board cuts in cash outlays and tax expenditures. In contrast, the Budget Control Act, passed to resolve the debt limit impasse, contains a sequester for discretionary and some mandatory spending, but no limits on tax expenditures.

Across-the-board cuts in tax expenditures would be complex, and possibly unworkable. OMB could, in principal, reduce all deductions, exclusions, and credits by set percentage, $x$, to meet a tax expenditure target, but that would require the partial inclusion of excluded income items such as employer-sponsored health insurance, pension contributions, and other fringe benefits, which would require employers to report the value of all of those items every year (against the chance that they might be partially taxable). In theory, a portion of tax-exempt interest might be made taxable. This would immediately add a risk premium to municipal bond yields, making them even less efficient as a way to aid state and local governments than they are now. As a practical matter, certain items, such as the tax break on pension contributions and the interest tax exemption, would probably be exempted from any sequester.

There's a question about whether depreciation and other timing preferences would also be reduced, but, if so, that would reduce future years' tax collections. It is unclear how to treat preferences such as the lower tax rates that apply to capital gains and dividends (although that's not an issue in the proposals of the president's fiscal commission or the Bipartisan Policy Center, since they would eliminate the rate differentials). One possibility would be to convert the 
alternate rates into partial exclusions - e.g., exclude 60 percent of long-term capital gains and dividends from tax. In the event of a sequester, $x$ percent of the excluded gains and dividends would be added back into taxable income.

The Bowles-Simpson failsafe plan requires cross-the-board cuts in cash outlays combined with proportional increases in statutory tax rates. This is more practical, but it does have the unintended side effect of making all deduction and exclusion preferences larger so part of the revenue gains are lost to larger expenditures. If the goal is to create an enforcement mechanism that is so painful that policymakers would be spurred to act, the combination of rate increases and automatic spending cuts might be effective because presumably liberals would want to avoid the indiscriminant spending cuts and conservatives would want to avoid the rate increases. On the other hand, there's a concern that if the mechanism is too draconian, policymakers will simply circumvent it—for example, by including legislation waiving the requirement or altering the caps along with the otherwise noncompliant spending legislation.

Another option in the BPC plan would be to adjust the VAT rate to offset tax expenditure overages. That would have several advantages. First, it would be relatively simple. Second, it would have smaller efficiency costs than increases in income tax rates. Third, assuming a very broad-based VAT, it would not increase the value of tax expenditures. Fourth, it would affect everyone, not just those with positive income tax liability. Burman (2009) argued that a VAT earmarked to pay for healthcare costs could help constrain healthcare costs because voters would be more amenable to otherwise unpopular cuts to Medicare and Medicaid spending if the alternative was a rising VAT rate. Of course, that assumes that policymakers do not respond to political pressure by simply severing the connection between the VAT and health spending.

Another option to limit tax expenditures is the proposal made by Martin Feldstein, Maya Maguineas, and Dan Feenberg (2011) to cap the value of certain tax expenditures at two percent of adjusted gross income (AGI). This approach has the drawback of significantly complicating compliance for some taxpayers and would remove almost all incentive effects from the affected tax expenditures. Feldstein, et al, point out that many taxpayers would face simpler tax returns because they would switch from itemizing to claiming the standard deduction, but for people with high enough incomes, it is effectively a new alternative minimum tax (where the minimum 
tax is calculated by eliminating the affected tax expenditures, recalculating tax and subtracting two percent of AGI). Furthermore, if the existing AMT remains, the interactions would be extremely complex-virtually impossible to manage without tax prep software in part because the standard deduction is an AMT preference item so the choice of whether to itemize would be very complicated. A much simpler alternative to Feldstein's scheme would be to simply eliminate the targeted tax expenditures and create a new standard deduction equal to the maximum of the existing standard deduction and eight percent of AGI, which would be approximately revenue neutral. That, however, would make it obvious that the tax expenditures had been eliminated, which Feldstein, et al, wanted to obscure in hopes that would make the proposal more politically saleable.

The advantage of Feldstein's tax expenditure limit is that it would make controlling individual income tax expenditures quite simple. The percentage of AGI could be adjusted to enforce the trigger. That is, it could be lowered to reduce the total value of tax expenditures to meet the cap. This is a decidedly second-best option (as all AMTs are), but it does have the virtue of making a tax expenditure limit practical. Also, starting with a higher percentage of AGI may ease the transition to the new regime. For example, the limit could start at six percent of AGI and phase down over the course of several years.

\section{Conclusion}

Policy analysts have long recognized that much spending is hidden in the tax code. Many tax expenditures are effectively open-ended entitlement programs like Social Security or Medicare, and even harder to monitor and control because they do not show up in traditional budget tables. Political scientist Chris Howard (1997) aptly named them “The Hidden Welfare State.”

This paper takes tax expenditure analysis one step forward by showing how the characterization of tax expenditures may systematically lead to more overall spending (bigger government), higher taxes, larger deficits, and a misallocation of resources away from cash

spending programs in favor of tax expenditures. For those who favor smaller government, more efficient government, and lower taxes, this should be a source of concern. Moreover, since tax expenditures tend to benefit families with higher incomes, the misallocation of scarce resources away from traditional spending programs may raise equity concerns as well. 
Integrating tax expenditures into the budget process and subjecting them (and all other spending) to effective controls could improve the efficiency of government and soften the blow from the belt tightening that is necessary if we are to avoid a debt crisis. An added benefit is that reductions in tax expenditures could simplify the income tax and make it less prone to abuse, especially if part of the revenues from the trimmed tax expenditures were used to cut marginal income tax rates. That is, controlling tax expenditures might increase the chances of enacting tax reform. 


\section{References}

Auerbach, Alan J. and William G. Gale, “Tempting Fate: The Federal Budget Outlook,” Tax Policy Center, June 30, 2011, http://www.taxpolicycenter.org/UploadedPDF/1001497-AuerbachGale-Tempting-Fate.pdf.

Bartlett, Bruce, “The Flawed Concept of Tax Expenditures,” National Center for Policy Analysis, 2001, http://www.ncpa.org/oped/bartlett/apr3001.html.

Jeffrey H. Birnbaum and Alan S. Murray, Showdown at Gucci Gulch: Lawmakers, Lobbyists, and the Unlikely Triumph of Tax Reform, Vintage Books, 1988.

Bipartisan Policy Center, "Restoring America’s Future: Reviving the Economy, Cutting Debt, and Creating a Simple, Pro-Growth Tax System,” 2010, http://bipartisanpolicy.org/sites/default/files/FINAL\%20DRTF\%20REPORT\%2011.16.10.pdf.

Blumenthal, Marsha, Laura Kalambokidis, P. Jay Kiedrowski, John Spry, Judy Temple, and Jenny Wahl, "Tax Expenditure Review Report: Bringing Tax Expenditures Into the Budget Process,” Minnesota Department of Revenue, February 2011, http://taxes.state.mn.us/legal_policy/Documents/TE_Review_Report_02_15_11.pdf.

Bradford, David, "Reforming Budgetary Language," in Sijbren Cnossen and Hans-Werner Sinn, eds., Public Finance and Public Policy in the New Century, Cambridge, MA: MIT Press, 2003, pp. 93-116.

Brooks, Neil, Review of Surrey and McDaniel (1985), Canadian Tax Journal, May-June 1986, 34(3), pp. 681-694.

Buckey, John L., “Tax Expenditure Reform: Some Common Misconceptions,” Tax Notes, July 18, 2011

Burman, Leonard E., "The Cost-Effectiveness of the Low-Income Housing Tax Credit Compared With Housing Vouchers," CBO Staff Memorandum, Congressional Budget Office, April 1992 (reprinted in Tax Notes, July 27, 1992).

Burman, Leonard E., “Taxing Capital Income Once,” Tax Notes, February 3, 2003.

Burman, Leonard E., and Alastair McFarlane, “Low-Income Housing Credit,” in Joseph J. Cordes, Robert D. Ebel, and Jane G. Gravelle, eds., The Encyclopedia of Taxation and Tax Policy, $2^{\text {nd }}$ edition, Washington, DC: The Urban Institute Press, 2005.

Burman, Leonard E., Jeffrey Rohaly, Joseph Rosenberg, and Katherine C. Lim. “Catastrophic Budget Failure,” National Tax Journal, September 2010, 63 (3), pp. 561-584. 
Burman, Leonard E., Eric Toder and Christopher Geissler, "How Big are Total Individual Tax Expenditures and Who Benefits From Them?” Tax Policy Center Discussion Paper Number 31, December 2008.

Davie, Bruce, "Tax Expenditures in the Federal Excise Tax System," National Tax Journal, Vol. 47, No. 1, March 1994, pp. 39-62.

Ellis, Ryan, "Why the Simpson-Bowles Tax Hike is Not the Same as Reagan’s 1986 Tax Reform Act -Tax revenue neutrality essential to true tax reform efforts," Americans for Tax Reform, 2010, http://www.atr.org/files/files/120210pr-sbnot1986.pdf.

Ernst and Young, Understanding the Dynamics V, Housing Credit Performance. 2010, http://www.ncsha.org/system/files/resources/Understanding+the+dynamics+V.pdf.

Hatch, Orrin, "In Speech, Hatch Warns of Dangers of Tax Hikes for Deficit Reduction,” Press Release, July 6, 2011, http://tinyurl.com/hatchexp.

Howard, Christopher, The Hidden Welfare State: Tax Expenditures and Social Policy in the United States. (Princeton: Princeton University Press) 1997.

Internal Revenue Service, “2010 Tax Statistics,” 2010, http://www.irs.gov/pub/irssoi/10taxstatscard.pdf.

Joint Committee on Taxation, Tax Expenditures for Health Care (JCX-66-08). July 30, 2008

Joint Committee on Taxation, Estimates of Federal Tax Expenditures for Fiscal Years 20092014 (JCS3-10). December 21, 2010.

http://www.jct.gov/publications.html?func=startdown\&id=3718.

Joint Committee on Taxation, Background Information on Tax Expenditure Analysis and Historical Survey of Tax Expenditure Estimates (JCX-15-11). February 28, 2011. http://www.jct.gov/publications.html?func=startdown\&id=3740.

Kleinbard, Edward, "Tax Expenditure Framework Legislation," National Tax Journal, 2010, 63(2), pp. 353-382.

Lucas, Deborah and Marvin Phaup, "The Cost of Risk to the Government and Its Implications for Federal Budgeting,” Measuring and Managing Federal Financial Risk, D. Lucas (ed), NBER Conference Report, University of Chicago Press, 2010, pp. 29-54

Lucas, Deborah and Marvin Phaup, "Reforming Credit Reform," Public Budgeting \& Finance, 2008, 28(4), pp. 90-110. 
National Commission on Fiscal Responsibility and Reform, The Moment of Truth, 2010, http://www.fiscalcommission.gov/sites/fiscalcommission.gov/files/documents/TheMomentofTru th12_1_2010.pdf

Obama, Barack, "Speech on Reducing the Budget," transcript in New York Times, April 13, 2011. http://www.nytimes.com/2011/04/14/us/politics/14obama-text.html

Peterson-Pew Commission on Budget Reform, Getting Back in the Black, 2010, http://www.budgetreform.org

Phaup, Marvin, "Federal Use of Implied Guarantees: Some Preliminary Lessons from the Current Financial Distress," Public Administration Review, July/August 2009, pp.651-659

Phaup, Marvin and Charlotte Kirschner, "Budgeting for Disasters: Focusing on the Good Times,” OECD Journal on Budgeting, 2010A, 1, 21-44.

Phaup, Marvin and Charlotte Kirschner, "Federal Budgeting in the United States," Comparative Public Budgeting: A Global Perspective, Charles Menifield (ed.) Jones and Bartlett, Sudbury, Mass., 2010B, Chapter 18, pp 329-349.

Saxton, Jim, “Tax Expenditures: A Review and Analysis,” Joint Economic Committee, http://www.house.gov/jec/fiscal/tax/expend.pdf, August 1999.

Schick, Allen, The Federal Budget: Politics, Policy, Process, $3^{\text {rd }}$ edition, Brookings: Washington, D.C., 2007.

Shaviro, Daniel. "Rethinking Tax Expenditures and Fiscal Language,” Tax Law Review, 2004, 57(2) , pp. 187-231.

Surrey, Stanley S., and Paul R. McDaniel, Tax Expenditures. (Cambridge, MA: Harvard University Press) 1985.

Toder, Eric, Bernard Wasow, and Michael P. Ettlinger, Bad Breaks All Around: The Report of The Century Foundation Working Group on Tax Expenditures. (New York: The Century Foundation Press) 2002.

U.S. Congressional Budget Office, Risk Exposure of the Pension Benefit Guaranty Corporation, September 2005. http://www.cbo.gov/ftpdocs/66xx/doc6646/09-15-PBGC.pdf

U.S. Congressional Budget Office, Responses to Questions about the Cost of a Cap-andTrade Program, Letter to the Honorable John F. Kerry, June 12, 2009.

http://www.cbo.gov/doc.cfm?index=10307\&zzz=39033

U.S. Congressional Budget Office, CBO’s Budgetary Treatment of Fannie Mae and Freddie Mac, January 2010. http://www.cbo.gov/ftpdocs/108xx/doc10878/01-13-FannieFreddie.pdf 
U.S. Office of Management and Budget, Analytical Perspectives, Budget of the United States Government, Fiscal Year 2003 (Washington, DC: Government Printing Office) 2002.

U.S. Office of Management and Budget, Analytical Perspectives, Budget of the United States Government, Fiscal Year 2011 (Washington, DC: Government Printing Office) 2010.

U.S. Treasury, “American Recovery and Reinvestment Act of 2009: Low-Income Housing Grants in Lieu of Tax Credit Allocations for 2009,” Fact Sheet, 2010. www.treasury.gov/initiatives/Documents/LIH_fact-sheet.pdf

Ura, Joseph Daniel, and Erica M. Socker, “The Behavioral Political Economy of Budget Deficits: How Starve the Beast Policies Feed the Machine,” The Forum: Vol. 9: Iss. 2, Article 7, 2011. http://www.bepress.com/forum/vol9/iss2/art7 